\title{
REPRODUCTIVE BIOLOGY IN SPECIES OF Bidens L. (Asteraceae)
}

\author{
Maria Tereza Grombone-Guaratini ${ }^{1 *}$; Vera Nisaka Solferini ${ }^{1}$; João Semir ${ }^{2}$ \\ ${ }^{1}$ UNICAMP - Depto. de Genética e Evolução - C.P. 6109 - 13083-970 - Campinas, SP - Brasil. \\ ${ }^{2}$ UNICAMP - Depto. de Botânica. \\ *Corresponding author <terezag@unicamp.br>
}

\begin{abstract}
Studies about reproductive biology of weed species can have implications on the establishment of controlling practices that minimize the effects of these weed populations on agricultural fields. The pollination biology of Bidens alba (L.) DC., B. pilosa L., and Bidens subalternans DC., was studied at different sites and climatic seasons. Bidens pilosa and B. subalternans are widely distributed in agricultural areas, in disturbed habitats, and along road sides. Bidens alba occur only along the coast. The three species are self-compatible and non agamospermous. The composition of the pollinator community changes during the year and between sites. Hymenopterans and lepidopterans are the most frequent visitors to Bidens species in both areas studied. Although the species are self-compatible, the presence of pollinators may affect the levels of inbreeding. The attraction of insects by Bidens species may be benefical to agricultural crop and may also have important implications for conservation biology.
\end{abstract}

Key words: floral visitors, pollination biology, weed species

\section{BIOLOGIA REPRODUTIVA EM ESPÉCIES DE Bidens L. (Asteraceae)}

\begin{abstract}
RESUMO: Estudos de biologia reprodutiva de espécies invasoras podem ter implicações sobre o estabelecimento de práticas de controle que minimizem o efeito das populações destas espécies em áreas agrícolas. A biologia da polinização de Bidens alba (L.) DC., B. pilosa L. e Bidens subalternans DC. foi estudada em diferentes locais e estações climáticas. Bidens pilosa e $B$. subalternans são espécies amplamente distribuídas em áreas agrícolas, em habitats perturbados e em margens de estradas. Bidens alba ocorre somente em regiões litorâneas. As três espécies são auto-compatíveis e não são agamospérmicas. A composição da comunidade de polinizadores apresenta diferenças durante o ano e entre locais. Himenópteros e lepidópteros são os visitantes mais freqüentes nas espécies de Bidens. Embora as espécies sejam auto compatíveis, a presença de polinizadores pode afetar os níveis de endocruzamento. A atração de insetos por espécies de Bidens pode beneficiar as culturas agrícolas e apresentar importantes implicações para a biologia da conservação.

Palavras-chave: visitantes florais, biologia da polinização, plantas daninhas
\end{abstract}

\section{INTRODUCTION}

Even though the botanical family Asteraceae is an important component of agricultural systems, little attention has been given to the biology of this family, and many aspects are still unexplained. Studies about reproductive biology of weed species can have implications on the establishment of controlling practices that minimize the effects of these weed populations on agricultural fields.

The Asteraceae are generalists, pollinated by several insects groups such as Coleoptera, Diptera and Hymenoptera (Noronha \& Gottsberger, 1980; Arroyo et al., 1982; Sazima \& Machado, 1983; Abbot \& Irwin, 1988; Herrera, 1990; Iwata, 1990; 1992). The genetic structure of generalist plant species may be significantly affected by the proportion of pollen transferred by different pollinators (Schmitt, 1980).
Bidens pilosa L. and B. subalternans DC. have similar morphology and habitat: both are therophyte herbs, widely distributed in agricultural and disturbed areas and along road sides in tropical and subtropical climates; both are invasive plants of annual and perennial crops. Bidens alba (L.) DC. life forms vary from herb to sub-arbust and are coastal in distribution.

Bidens pilosa usually has discoid flower heads (without ray florets). However, a radiate morph (the ray florets have ligules) is also common throughout most of this species. Bidens subalternans and B. alba have only flowering heads with ray florets. The major function of the ray florets in most species of Asteraceae is related to the attraction of pollinators (Sun \& Ganders, 1990).

Plants that occur in disturbed areas are usually self-compatible (Baker, 1974). In such plants, the number of flowers visited by pollinators may determine the proportion of the seed set that is selfed or outcrossed, and 
this will affect the levels of inbreeding. Furthermore the proportion of seasonal pollinators and the different foraging behavior of the pollinators may affect the neighborhood area. This process ensures high genetic variability (Palmer et al., 1988; Campbell \& Waser, 1989).

Except for some reports on North and Central American species (Ballard, 1986; Jaimes \& Ramírez, 1999), there is no information on the reproductive biology of Bidens species. This research identifies the pollinator community of Bidens species and examines the relationship between pollinators and flower head morphology. The mating systems in three Bidens species was also assessed.

\section{MATERIAL AND METHODS}

Bidens alba: Herb to sub-arbust 0.4-1.2 m tall, green or vine colored, erect or dorsal decumbent, square, stems; radiate flower heads, white, reflexed and sterile, ray-florets 6-16 mm long; yellow, tubular disc-florets, $5.5 \mathrm{~mm}$ long; cypselas dark brown, costate, $10 \mathrm{~mm}$ long, chiefly with two awns (Figure 1).

Bidens pilosa: Annual herbs 0.3-1.0 m tall, green or vine colored, erect or dorsal decumbent, square, stems; discoid or radiate flower heads, when present, white to salmon, sterile ray-florets, $5 \mathrm{~mm}$ long; yellow, longer, disc-florets; when presents disc-florets, yellow, tubular and ca. $5 \mathrm{~mm}$ long; cypselas dark brown, costate, 5-11 mm long, chiefly with three awns (Figure 1).
Bidens subalternans: Annual herbs 0.3-1.2 m tall, green or vine colored, erect, square, stems; radiate flower heads, yellow, sterile, 5-6 mm long; ray-florets always present; disc-floret yellow, tubular, ca. $5 \mathrm{~mm}$ long; cypselas dark brown, costate, $6.5-11 \mathrm{~mm}$ long, chiefly with four awns (Figure 1).

Field methods: Data were collected for populations of B. pilosa and B. subalternans at two sites: a) an abandoned area in Campinas $\left(21^{\circ} 52^{\prime} \mathrm{S}, 46^{\circ} 25^{\prime} \mathrm{W}\right)$, and $\left.\mathrm{b}\right)$ an agricultural area in Piracicaba $\left(18^{\circ} 28^{\prime} \mathrm{S}, 48^{\circ} 25^{\prime} \mathrm{W}\right)$. Bidens alba achenes came from Cubatão, SP (23 $52^{\prime}$ S and $46^{\circ} 25^{\prime} \mathrm{W}$ ) and were cultivated together with the other species only in Campinas, SP. Data of this species were collected in Campinas.

Floral visitors of each species were observed during four, non-consecutive days (one day interval between each observation), four consecutive hours per day. The observations were made in April and May (dry season) and in November and December (wet season of 2000). Captured insects were analyzed for the presence of pollen. The relative abundance of visitors was estimated based on the number of visits by each insect group compared to the total number of visits

For B. pilosa it was examined whether radiate plants were more attractive to pollinators than non-radiate ones. Two potted plants of each type were combined in four artificial groups. Visitors to these plants were recorded during four, non-consecutive days, four consecu-
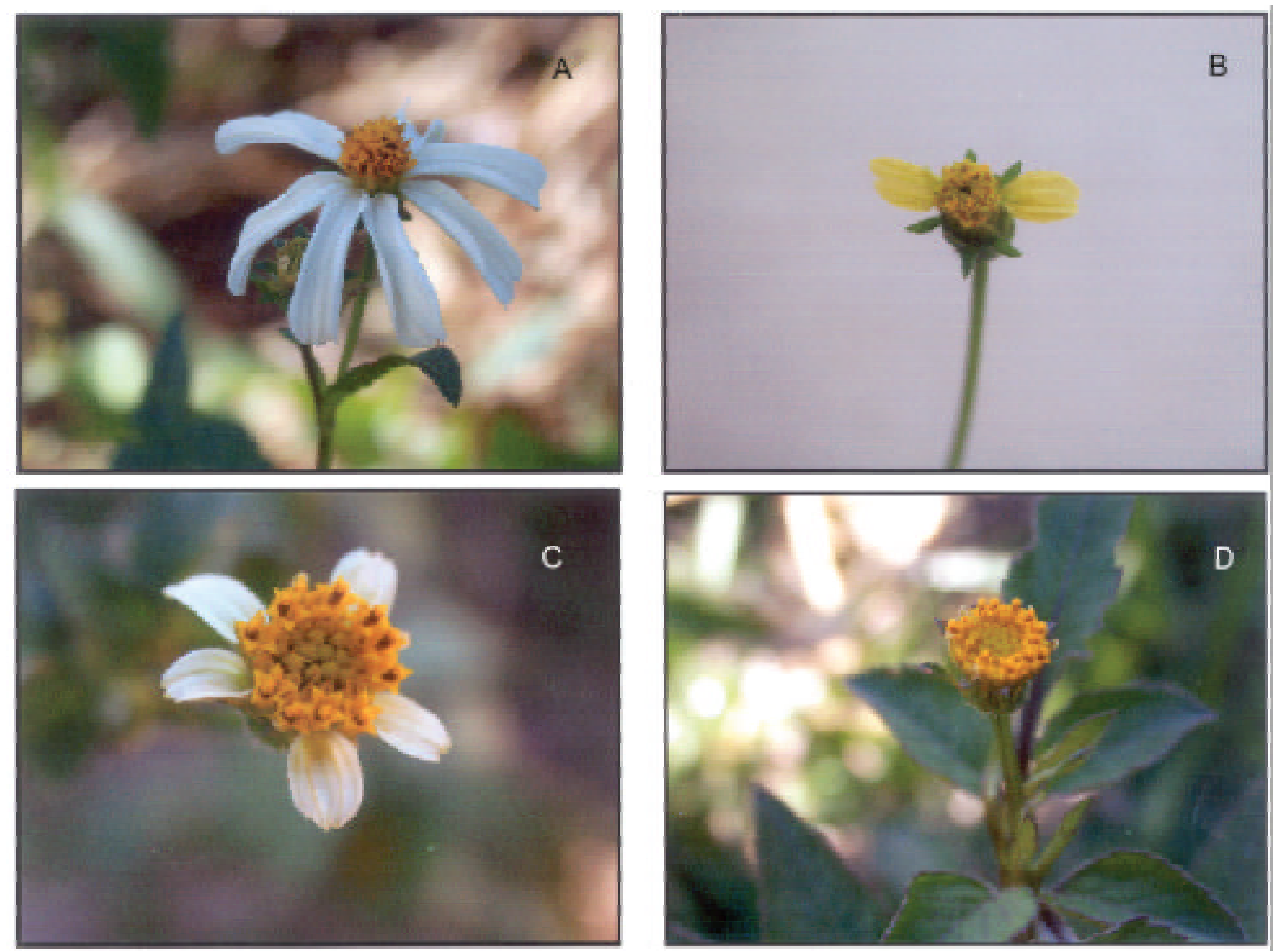

Figure 1 - A) Bidens alba flower head; B) B. subalternans flower head; C). B. pilosa radiate flower head and D) B. pilosa discoid flower head.

Sci. Agric. (Piracicaba, Braz.), v.61, n.2, p.185-189, Mar./Apr. 2004 
tive hours per day. The daily hours were divided into 15 min periods so that data could be obtained by alternating between groups.

Mating system: The sample size was 15 plants per species. Automatic self-compatibility was investigated in 25 bagged flower heads at the budge stage. Agamospermy was estimated in 25 bagged flower heads at the budge stage in which the anthers were removed to prevent selfpollination. Twenty five open heads were used as controls. All cypselas from marked flower heads were collected, counted, germinated under controlled conditions $\left(20^{\circ}-30^{\circ} \mathrm{C} ; 12 \mathrm{~W}\right.$ light/ dark).

Statistical analysis: The number of cypselas showing from automatic self-pollination, open pollination and agamospermy was analysed using Student's t-test for independent samples. The number of viable cypselas from automatic self-pollination and open pollination, was analyzed by $\chi^{2}$ test. The $\chi^{2}$ test for independent samples was also used to compare the frequency of insect visits between radiate and non-radiate plants. All of the statistical tests were done as described in Zar (1999).

\section{RESULTS AND DISCUSSION}

Anthesis of the flower head occurs early in the morning (7h00-8h00). One or two flowers open per day in centripetal sequence. The main resource offered to pollinators is nectar, but pollen is also sought by insects.

The radiate flower head has peripheral ray florets that are either female or sterile, and are with white, salmon or yellow; the inner disc florets are tubular, bisexual and yellow. The discoid flower head consists of only tubular, bissexual, yellow florets. There are five stamens united in an anther tube with free filaments. The florets are protandrous and during the male phase there is secondary pollen presentation; the anther has longitudinal dehiscence, which keeps the pollen within the anther tube. When the stile grows, it passes along the anther tube and the pollen grains are trapped among the sterile hairs on the stile arms. During the female phase, the still arms open and expose the inner receptive surface. As result, self pollen remains outside on the receptive surface.

Floral visitors: Insects of various orders were observed visiting the flower heads of all species (Table 1). The community of floral visitors differed between the study sites. In addition, the relative abundance of visitors in the insects groups differed among populations (Table 2).

Hymenopterans were responsible for $67 \%-93 \%$ of the visits at both studied sites (Tables 1 and 2). Most of the hymenopterans were solitary bees, except for the family Apidae, whose members are social and have perennial colonies (Roubik, 1989). Solitary bees are consid-
Table 1 - Floral visitors to Bidens alba, B. pilosa and B. subalternans at both study sites in different seasons.

\begin{tabular}{lcc}
\hline Visitors & \multicolumn{2}{c}{ Campinas Piracicaba } \\
\cline { 2 - 3 } & March-April/2000 & Nov-Dec/2000 \\
\hline Diptera &
\end{tabular}

Shirphidae

Pseudodoros cf. X X

\begin{tabular}{ll} 
Parcophagidae & $\mathrm{X}$ \\
sp. 1 & $\mathrm{X}$ \\
$\mathrm{sp} .2$ & $\mathrm{X}$ \\
\hline
\end{tabular}

\section{Hymenoptera}

Anthophoridae

\begin{tabular}{|c|c|c|c|c|}
\hline Ceratina volitans & $\mathrm{X}$ & $X$ & & \\
\hline Ceratina sp. & & $\mathrm{X}$ & & \\
\hline \multicolumn{5}{|l|}{ Apidae } \\
\hline Apis mellifera & & & $\mathrm{X}$ & \\
\hline Exomalopsis auropilosa & $\mathrm{X}$ & $\mathrm{X}$ & $X$ & $\mathrm{X}$ \\
\hline Nomada sp. & & & & $\mathrm{X}$ \\
\hline Paratetrapedia sp. & & & & $\mathrm{X}$ \\
\hline Tetrapedia sp. & & & & $\mathrm{X}$ \\
\hline \multicolumn{5}{|l|}{ Halictidae } \\
\hline Augoclora sp. 1 & $\mathrm{X}$ & & & \\
\hline Augoclora sp. 2 & $\mathrm{X}$ & $\mathrm{X}$ & $\mathrm{X}$ & $\mathrm{X}$ \\
\hline Augocloropsis sp. 1 & $\mathrm{X}$ & $\mathrm{X}$ & $\mathrm{X}$ & \\
\hline Dialictus sp. & & $\mathrm{X}$ & & \\
\hline
\end{tabular}

Megachilidae

\begin{tabular}{llcc} 
Dicranthidium gregarium & & $\mathrm{X}$ & $\mathrm{X}$ \\
Epanthidium tigrinum & & $\mathrm{X}$ & \\
Hypanthidium nigritulum & & $\mathrm{X}$ & $\mathrm{X}$ \\
Moureana sp. & & $\mathrm{X}$ \\
Vespideae & & $\mathrm{X}$ & \\
Ammophila gracilis & $\mathrm{X}$ & & $\mathrm{X}$ \\
sp. 1 & $\mathrm{X}$ & & $\mathrm{X}$ \\
sp. 2 & & & \\
\hline
\end{tabular}

\section{Lepidoptera}

Hesperidae

$\begin{array}{lll}\text { Lerodea erythrostica } & \mathrm{X} & \\ \text { Pyrgus communis } & & \mathrm{X} \\ \text { Pyrgus oileus } & \mathrm{X} & \mathrm{X} \\ \text { sp. } 1 & & \mathrm{X} \\ \text { sp. } 2 & & \mathrm{X} \\ \text { Urbanus dorantes } & \mathrm{X} & \end{array}$

Urbanus dorantes $\quad \mathrm{X}$

\begin{tabular}{llcc} 
Nymphalidae & & & \\
Anartia jathrophae & & $\mathrm{X}$ & \\
$\begin{array}{l}\text { Closyne lacinia } \\
\text { Euptoitea hegesia }\end{array}$ & $\mathrm{X}$ & $\mathrm{X}$ & $\mathrm{X}$ \\
Hemiagrus hanno & $\mathrm{X}$ & & \\
Hermeuptica hermes & $\mathrm{X}$ & & $\mathrm{X}$ \\
Strimon sp. & & $\mathrm{X}$ & \\
Leptotes cassius & & & \\
Pieridia & & & $\mathrm{X}$ \\
Eurema nise & $\mathrm{X}$ & & \\
\hline
\end{tabular}


ered efficient pollinators since they have a tendency to collect pollen and nectar simultaneously. These insects forage at different times of the day and prefer heads with greater proportion of florets in the male phase (Lane, 1996).

Lepidopterans, particularly Nymphalidae, were abundant at both sites (Table 1 and 2). Visitation by Lepidoptera has been reported for Bidens (Arroyo et al., 1982; Abbot \& Irwin, 1988; Sun \& Ganders, 1990; Cabrera \& Dieringer, 1992; Iwata, 1992). Butterflies are important pollinators of Asteraceae flowers and represent nearly $75 \%$ of all visitors (Mani \& Saravanan, 1999). According to some authors, the irregular, unpredictable and random foraging behavior of butterflies may improve the genetic variability of plants. In the study areas, butterflies were responsible for $1.5 \%-26 \%$ of all visits. Butterflies remain on the plants for up to $60 \mathrm{~s}$, but no pollen was found on their bodies. If there is any role for these insects in the pollination of Bidens, it is probably of minor importance.

Three dipteran species of the families Syrphidae and Sarcophagidae were observed visiting Bidens alba, B. pilosa and B. subalternans. Many Syrphidae are considered important pollinators of Asteraceae (Mani \& Saravanan, 1999). There are no other reports of Sarcophagidae visiting flower heads.

Radiate versus non-radiate plant morphs: The results from the mixed plots showed that pollinators made 65\% of their visits to discoid plants ( $N=101$ visits, $\chi^{2}=9.51$; $\mathrm{df}=1 ; P<0.05)$. Many authors suggest that the presence of ray-flowers in the Asteraceae is an adaptation to make the heads more attractive to pollinators (Stuessy et al., 1986). In addition, some studies have shown that radiate heads have greater outcrossing rates than discoid ones (Marshall \& Abbot, 1982; Abbott \& Irwin, 1988; Sun \& Ganders, 1990). However, contrary to these observations, no evidence was found that insects preferentially visited radiate plants. Similar results were reported by Gross \& Werner (1983) and Andersson \& Widén (1993). The presence of ray flowers in Bidens is not important in attracting pollinators.

Table 2 - Relative abundance of visits by each insect group found on Bidens pilosa and B. subalternans at the two study sites.

\begin{tabular}{|c|c|c|c|c|}
\hline \multirow[b]{2}{*}{ Visitant } & \multirow{2}{*}{\multicolumn{2}{|c|}{$\begin{array}{c}\text { Campinas Piracicaba } \\
\text { March-April } \\
2000\end{array}$}} & \multirow{2}{*}{\multicolumn{2}{|c|}{$\begin{array}{c}\text { Campinas Piracicaba } \\
\text { November-December } \\
2000\end{array}$}} \\
\hline & & & & \\
\hline Diptera & $\begin{array}{c}6 \\
(6.3 \%)\end{array}$ & $\begin{array}{c}3 \\
(4.8 \%)\end{array}$ & $\begin{array}{c}3 \\
(2.2 \%)\end{array}$ & $\begin{array}{c}4 \\
(3.7 \%)\end{array}$ \\
\hline Hymenoptera & $\begin{array}{c}71 \\
(67.4 \%)\end{array}$ & $\begin{array}{c}59 \\
(93.7 \%)\end{array}$ & $\begin{array}{c}118 \\
(76.6 \%)\end{array}$ & $\begin{array}{c}78 \\
(70.3 \%)\end{array}$ \\
\hline Lepidoptera & $\begin{array}{c}17 \\
(26.3 \%) \\
\end{array}$ & $\begin{array}{c}1 \\
(1.5 \%) \\
\end{array}$ & $\begin{array}{c}33 \\
(21.2 \%) \\
\end{array}$ & $\begin{array}{c}29 \\
(26 \%) \\
\end{array}$ \\
\hline Total & 94 & 63 & 154 & 111 \\
\hline
\end{tabular}

Mating system: The three species studied are self-compatible (Table 3). There was no significant difference between the germination of self-pollinated and control cypselas (Table 4). None of the species investigated showed agamospermy. Before anthesis, the stile branches were partially separated and had pollen on their receptive surface. Sun \& Ganders (1990) reported similar observation for Bidens pilosa. According to these authors, this mechanism may ensure pollination in the absence of pollinators, or may be caused by the age of the flower (Patil, 1980 apud Lane, 1996). The presence of pollinators may influence the amount and distribution of genetic variability in self-compatible plants (Maimoni-Rodella \& Rodella, 1992) and the number of flowers visited per plant will determine the proportion of seeds set that are selfed or outcrossed (Schimitt, 1980).

Bidens pilosa (hairy beggarticks) and $B$. subalternans (beggarticks) are species that have development resistance against herbicides in Brazil (Monquero et al., 2003). The pollinator foraging behavior could promote gene flux among resistants (R) and non resistents (S) plants, easing the spread of R-plants in crops. The importance of studying local communities of floral visitors goes beyond the interest in the biology of a given species and a knowledge of potential pollinators is relevant when choosing for cultivation and has implications for conservation biology (Waser et al., 1996).

The species found at sea level was identified by Magenta (1998) as Bidens alba. In North America, this species is self-incompatible (Ballard, 1986). Differences in the size of the ray florets and the number of awns plus mating system relative to other Bidens suggest the presence of a new Brazilian species of Bidens with a coastal distribution.

Generalist plants, such as B. alba, B. pilosa and B. subalternans, represent an important food resource for

Table 3 - Mean number of cypselas from self-pollination and open pollination in three Bidens species.

\begin{tabular}{|c|c|c|c|}
\hline \multirow[t]{2}{*}{ Species } & \multicolumn{2}{|c|}{ Mating system } & \multirow[b]{2}{*}{$t(\mathrm{p})$} \\
\hline & Self-pollination & $\begin{array}{c}\text { Open } \\
\text { pollination }\end{array}$ & \\
\hline B. alba & $48.7 \pm 8.7$ & $47.4 \pm 5.6$ & $0.54(>0.05)$ \\
\hline B. pilosa & $45.5 \pm 7.6$ & $43.7 \pm 8.8$ & $0.77(>0.05)$ \\
\hline B. subalternans & $58.6 \pm 6.4$ & $60.2 \pm 8.2$ & $0.47(>0.25)$ \\
\hline
\end{tabular}

Table 4 - Number of viable cypselas from self-pollination and open pollination in three Bidens species.

\begin{tabular}{|c|c|c|c|}
\hline \multirow[t]{2}{*}{ Species } & \multicolumn{2}{|c|}{ Mating system } & \multirow[b]{2}{*}{$\chi^{2}(\mathrm{p})$} \\
\hline & Self-pollination & $\begin{array}{c}\text { Open } \\
\text { pollination }\end{array}$ & \\
\hline B. alba & $89(67 \%)$ & $83(62 \%)$ & $1.00(>0.5)$ \\
\hline B. pilosa & $80(80 \%)$ & $81(81 \%)$ & $0.04(>0.05)$ \\
\hline B. subalternans & $53(53 \%)$ & $44(44 \%)$ & $1.62(>0.25)$ \\
\hline
\end{tabular}


hymenopterans and dipterans. These plants may be important components of agroecosystems because they play a significant role in sustaining communities of insects that contribute to crop growth.

\section{ACKNOWLEDGEMENTS}

The authors would like Stephen Hyslop for reviewing the English, to Beatriz W. T. Coelho, Fernando Silveira, Sérvio T. P. Amarante for identifying Hymenoptera and André V. L. Freitas for identifying Lepidoptera. This work was supported by FAPESP, grant No. 98/05085-2 to T. M. Lewinsohn within the BIOTAFAPESP program. M.T. Grombone-Guaratini was supported by FAPESP (fellowship No. 99/05493-6).

\section{REFERENCES}

ABBOT, R.J.; IRWIN, J.A. Pollinator movements and the polymorphism for outcrossing rate at the ray locus in commongroundsel, Senecio vulgaris. Heredity, v.60, p.295-298, 1988.

ANDERSSON, S.; WIDÉN, B. Pollinator-medated selection on floral traits in a synthetic population of Senecio integrifolius (Asteraceae). Oikos, v.66, p.72-79, 1993.

ARROYO, M.T.K.; PRIMACK, R.; ARMESTO J. Community studies in pollination ecology in the high temperate Andes of Central Chile, I, Pollination mechanisms and altitudinal variation. American Journal of Botany, v.69, p.82-97, 1982.

BAKER, H.G. The evolution of weeds. Annuals Review of Ecology and Systematics, v.5, p.1-25, 1974.

BALLARD, R. Bidens pilosa complex (Asteraceae) in North and Central America. American Journal of Botany, v.73, p.1452-1465, 1986.

CABRERA, R.L.; DIERINGER, G. Reproductive biology population of Acourtia runcinata (Asteraceae: Mutisieae) at the northeastern limit of its range. American Midland Naturalist, v.128, p.83-88, 1992.

CAMPBELL, D.R.; WASER, N.M. Variation in pollen flow within and among populations of Ipomopsis aggregata. Evolution, v.43, p.14441555,1989

GROSS, D.S.; WERNER, P.A. Relationships among flowering phenology, insect visitors, and seed-sets of individuals: experimental studies on four co-occurring species of goldenroad (Solidago: Compositae). Ecological Monographs, v.53, p.95-117, 1983.

HERRERA, C.M. Daily patterns of pollinator activity, differential pollinating effectiveness, and floral resource availability, in a summer-flowering Mediterranean shrub. Oikos, v.58, p.277-288, 1990.

IWATA, M. Studies on the insects community of flowers: I. The interspecific relations among flower visiting insects in Iriomote Island. Proceedings of the Faculty of Agriculture of Kyushu Tocai University, n.9, p.1724, 1990.

IWATA, M. Studies on the insects community of flowers: II. The interspecific relations among flower visiting insects in Iriomote Island. Proceedings of the Faculty of Agriculture of Kyushu Tocai University, n.11, p.99$107,1992$.
JAIMES, I.; RAMÍREZ, N. Breeding systems in a secondary deciduous forest in Venezuela: the importance of life form, habitat, and pollination specificity. Plant Systematic and Evolution, v.215, p.23-36, 1999.

LANE, M.A. Pollination biology of Compositae. In: CALIGARI, P.D.S.; HIND, D.J.N (Ed.) Compositae: biology \& utilization. Kew: Royal Botanical Garden, 1996. chap.5, p.61-81.

MAGENTA, M.A.G. As subtribos Ambrosiinae, Galinsoginae e Coreopsidinae (Heliantheae - Asteraceae) no Estado de São Paulo, São Paulo: USP/IB, 1998. 140p. (Dissertação (Mestrado).

MAIMONI-RODELLA, R.C.S.; RODELLA, R. Biologia floral de Ipomoea acuminata Roem et Scult. (Convolvulaceae). Revista Brasileira de Botânica, v.15, p.129-133, 1992.

MANI, M.S.; SARAVANAN, J.M. Pollination ecology and evolution in Compositae (Asteraceae). New Hampshire: Science Publishers, 1999. $166 \mathrm{p}$.

MARSHALL, D.F.; ABBOTT, R.J. Polymorphism for outcrossing frequency at the ray floret locus in Senecio vulgaris L. I. Evidence. Heredity, v.48, p.227-235, 1982 .

MONQUERO, P.A.; CHRISTOFFOLETI, P.J.; CARRER, H. Biology, mamagement and biochemical/genetic characterization of weed biotypes resistant to acetolactate synthase inhibitor herbicides. Scientia Agricola v.60, p.495-503, 2003.

NORONHA, M.R.; GOTTSBERGER, G. A polinização de Aspilia floribunda (Asteraceae) e Coclospermum regium (Coclospermaceae) e a relação das abelhas visitantes com outras plantas do cerrado de Botucatu, Estado de São Paulo. Revista Brasileira de Botânica, v.3, p.67-77, 1980.

PALMER, M.; TRAVIS, J.; ANTONOVICS, J. Seasonal pollen flow and progeny diversity in Amianthium muscaetoxicum: ecological potential for multiple mating in a self-incompatible, hermaphroditic perenial. Oecologia, v.77, p.19-24, 1988.

ROUBIK, D.W. Ecology and natural history of tropical bees. Cambridge: Cambridge University Press, 1989. 514p.

SAZIMA, M.; MACHADO, I.C. Biologia floral de Mutisia coccinia St. Hil. (Asteraceae). Revista Brasileira de Botânica, v.6, p.103-108, 1983.

SCHMITT, J. Pollinator foraging behavior and gene dispersal in Senecio (Compositae). Evolution, v.34, p.934-943, 1980.

STUESSY, T.F.; SPOONER, D.M.; EVANS, K.A. Adaptative significance of raycorollas in Helianthus gorsseserratus (Compositae). American Midland Naturalist, v.115, p.191-197, 1986.

SUN, M.; GANDERS, F.R. Outcrossing rates and allozyme variation in rayed and rayless morphs of Bidens pilosa. Heredity, v.64, p.139-143, 1990.

WASER, N.M.; CHITTKA, L.; PRICE, M.V.; WILLIAMS, N.M.; OLLERTON, J. Generalization in pollination systems, and why matters. Ecology, v.77, p.1043-1060, 1996.

ZAR, J.H. Biostatistical analysis. 4.ed. New Jersey: Prentice Hall International Editions, 1999. 663p.

Received January 06,2003

Accepted January 28, 2004 